7. Lieberman, Devorah, and Glenn Gamst. "Intercultural Communication Competence Revisited: Linking the Intercultural and Multicultural Fields." International Journal of Intercultural Relations 48 (2015): 17-19.

8. Mackenzie, Lauren. "Strategic Enablers: How Intercultural Communication Skills Advance Micro-Level International Security." The Journal of Culture, Language and International Security 1 (2014): 1, 85-96.

9. Miller, John, and Jennifer Tucker. "Addressing and Assessing Critical Thinking in Intercultural Contexts: Investigating the Distance Learning Outcomes of Military Leaders." International Journal of Intercultural Relations 48 (2015): 120-136.

10. Orna-Montesinos, Concepción. (2017). The scope of intercultural communication in a military-specific language learning program. Journal of English for Specific and Academic Purposes. 5. 13-33.

11. Tomalin, Barry. "Culture - The Fifth Language Skill." (2008). Available from: http://www.teachingenglish.org.uk/articles/culture-fifthlanguage-skill

DOI https://doi.org/10.30525/978-9934-588-90-7-90

\title{
АУДІОЛІНГВАЛЬНИЙ МЕТОД ПРИ ВИКЛАДАННІ АНГЛІЙСЬКОЇ МОВИ
}

\author{
Харіна А. В. \\ вчитель англійської мови \\ BUKI Company \\ Украӥна
}

Методика викладання іноземних певний час здійснювала акцент на виборі раціональних методів навчання. I ніколи не існувало єдиного найкращого методу для всіх, та і не завжди можливо та доречно було застосовувати одну і ту ж методологію до всіх учнів, які мають різні цілі, середовище та навчальні потреби. Досвідчений фаховий викладач мови завжди застосовує підхід принципової еклектики, приймаючи рішення про найбільш доречні техніки.

Всі методи покликані здійснити позитивний та негативний вплив, але обов'язково мають нести об'єктивну цінність. Протягом тривалого часу методи викладання мови залежали від суспільства, яке задавало тон, мету, зміст та форму навчання іноземної мови. I якраз одним із них був аудіолінгвальний метод. Він був створений Чарльзом Фрізом на основі 
ідей Гарольда Пальметра. Фріз розглядав цей метод у чіткій системі знаковій системі, вважаючи, що письмо є штучним, а усне мовлення природним способом оволодіння мовою.

Аудіомовна методика спрямована на розвиток комунікативної компетентності учнів за допомогою діалогів. Діалоги та навчальні вправи, які студентам потрібно повторити, використовуються для формування у учнів звичок, які дозволять їм виробляти швидкі та автоматичні реакції. Таким чином, метою аудіомовного методу $\epsilon$ комунікативне використання цільової мови. Відповідно до цього методу мовленню надається пріоритет у навчанні іноземних мов. Студенти вивчають цільову мову в конкретному контексті, який дозволить їм пов'язати вивчене з реальними навчальними середовищами.

Лінгвістичними цілями цього методу $є$ : 1 . здатність розуміти іноземну мову, коли на ній говорять із звичайною швидкістю і пов'язані зі звичайними справами, 2. здатність розмовляти прийнятною вимовою та граматичною правильністю, 3. ті, хто вивчають мови, не мають труднощів у розумінні друкованих та усних матеріалів. Вищезазначені цілі мають основні принципи у навчанні взаємодії викладання. Оскільки основною метою є здатність до спілкування, то ті, хто вивчають мову та ï вчитель мови повинні постійно використовувати цільову мову. Вчитель мови повинен привітати своїх учнів цільовою мовою з першого дня їхнього заняття з мови. Їхня рідна мова не використовується, якщо це не потрібно, а переклад на їх рідну мову заборонено. Слід проводити інтенсивні тренування, щоб учні мали достатньо практики використання розмовної мови. Аудіовізуальний метод $є$ центральним. За допомогою цього методу учні, які вивчають мову, вивчають структури, звуки чи слова в контексті. А серед інших навичків формуються читання та письмо, що відкладаються до засвоєння мови.

Розвиток усного мовлення $\epsilon$ домінантною метою у вивченні мови, у той час, як граматика викладається структурно та узагальнено. Лексичному рівню мови віддається левова частка, а у цілому головною метою $\epsilon$ передача звуків, які вивчаються. Так, ми маємо вирізняти продуктивні та рецептивні види мовлення і відповідно до типу підбирати інформаційні джерела. Під час вибору рецептивних видів вчителям необхідно дотримуватись принципу частотності, а продуктивного - вживаності синонімів. Головні слова запам'ятовуються відразу, а другорядні потім. У результаті такого навчання учні запам'ятовують так кількість слів: для усного мовлення - 1000, письмового - близько 4 тисяч, під час читання близько 7 тисяч [1, стор. 60].

Важливим завданням при вивченні іноземної мови $є$ позбавлення від негативного впливу рідної мови. Це одна із складностей, яка виникає при вивченні мови. I це, до речі, і вирізняє аудіолінгвальний метод від інших 
методів. Фріз був проти читання на початковому етапі вивчення мови, бо він віддавав перевагу розвитку комунікативної функції. Тож його метод полягав у тісному зв'язку із структурами мови, і це мало вплив на суспільство. За його дослідженнями, учень засвоює мову у такій послідовності: заучування, усвідомлення, інтенсивне тренування, вільне спілкування.

Під час практики аудіолінгвального методу необхідно працювати 3 діалогами на засвоєння граматичних структур. А вже на заключному етапі вчити діалоги напам'ять. Всі практичні завдання потрібно виконувати без використання тексту, тобто без опори. Таким чином здійснюється акцент на структурах, у той час, як лексика відіграє проміжну роль. I саме це дає підстави вважати аудіолінгвальний метод пріоритетним.

Аудіолінгвальний метод має за мету розвинути комунікативну компетентність учнів за допомогою діалогів та тренувань. Використання діалогів та тренувань $є$ ефективним у навчанні іноземних мов, оскільки вони спонукають студентів до мовлення. Повторення діалогів та тренувань дозволить студентам швидко та точно реагувати розмовною мовою.

\title{
Література:
}

1. Колкер Я. М. Практическая методика обучения иностранному языку. - М. : Academia, 2001. - 258 c.

2. Методика викладання іноземних мов у середніх навчальних закладах: Підручник / Під ред. С. Ю. Ніколаєвої. - К.: Ленвіт, 2002. - 328 с.

DOI https://doi.org/10.30525/978-9934-588-90-7-91

\section{СОЦІКУЛЬТУРНИЙ АСПЕКТ НАВЧАННЯ ІНОЗЕМНІЙ МОВІ}

\author{
Шотова-Ніколенко Г. В. \\ кандидат філологічних наук, \\ дочент кафедри іноземних мов \\ Одеський державний екологічний університет \\ м. Одеса, Україна
}

Культурне розмаїття повинне бути важливим засобом збереження людських цінностей. Вивчення іноземної мови означає наближення до інших культурних цивілізацій, розвиток інтелекту для зустрічі 3 реальним і невідомим, збагачення себе через знання інших культур і їх світосприйняття. 